\title{
Comunicação Visual e Impressos no Serviço Público
}

LUIZ SANTA CRUZ

Redator da Agência Nacional. Adjunto da Secretaria de Imprensa do Presidente da República.

$\mathrm{Na}$ grande crise moderna da chamada intelligentsia "em perigo de morte", como receia Marcel de Corte, face à vaga avassaladora da "informação deformante" 1 - o que se vê de fato em jôgo é o próprio destino da democracia. Sente-se esta desarvorada, e como tomada de pânico, diante de uma cultura e de uma civilização novas, geradas na História à sua revelia e ante seus olhos ainda atônitos, pela brusca irrupção da era tecnológica, trazendo em seu bôjo a sua tentacular - e já agora irreversível - "comunicação social" ou "informação de massa".

$\mathrm{Na}$ atual terminologia da informação, sabemos que se denomina "comunicação social" ou "informação de massa" ao tipo hodierno da informação mecânicamente organizada e no qual o emissor ou comunicador funciona como simples peça na complexa engrenagem de transmissão das mensagens, dirigidas tôdas elas às grandes audiências heterogêneas e anônimas - os seus receptores, ou, no estranho neologismo anglolatino, a sua mass-média.

Tais mensagens são as mais variadas e diferentes modalidades, desde a das transmissões educativas, a dos informes governamentais, as informações-noticias, até às mais numerosas promoções comerciais que geram, em verdadeiros partos publicitários, o nôvo consumidor-autômato dos produtos anunciados. Ou se pode tratar ainda de comunicação de lazer ou de entretenimento, como seja a transmissão de palavras e imagens com a intenção preconcebida de apenas distrair o receptor, tais como o teatro de massa de TV e rádio, a música

1 L'Intelligence en péril de mort, Marcel de Corte, Editions du Club de la Culture Françalse, Paris, 1969, cap. III. 
popular, as programações recreativas de televisão, a revista em quadrinhos, o cinema, os comics, a imprensa literária, o turismo, os motéis, os livros de bôlso, etc. Tudo isso que nos traz incessantemente o mundo audiovisual dos teletipos, das rotativas, das películas foto e cinematográficas, dos tapes, das fitas magnéticas, das antenas de rádio, de TV e dos satélites intelsats. Pois, não há, a bem dizer, um só segundo em que "uma molécula de ar não vibre com as mensagens que um aparelho, ou um gesto tornam logo audíveis e visíveis", rodando-se um botão, ou ligando-se mera tomada de corrente. ${ }^{2}$

É o que o sociólogo europeu da "cultura de massa", Edgar Morin, em L'Esprit du Temps ${ }^{3}$, chama de "a segunda colonização", não mais geográfica ou horizontal, como a das Américas, da Ásia e da África, mas psicológica ou vertical, penetrando e colonizando a grande reserva territorial que é a alma do homem moderno, e, numa "segunda industrialização", industrializando-lhe a mente e a vontade. A "aristocracia cultural", os intelectuais, a intelligentsia recusa-se a aceitar ou, ao menos, reconhecer essa Terceira Cultura, que a moderna sociologia americana, após a $2^{\text {a }}$ Guerra Mundial, vem pesquisando, autenticando e tentando mesmo dela participar.

Pode, portanto, à essa altura do desenvolvimento e da diversificação da "comunicação social" ou da "informação de massa", a resistente intelligentsia deixá-la à própria sorte, entregue às garras tentaculares do seu câncer totalitário da "informação deformante", a que alude Marcel de Corte? Ou deve, ao contrário, conhecê-la bem, a fim de melhor neutralizar-lhe as irradiações mortíferas, reconduzindo-a, sob a gestão da própria inteligência, como faculdade reitora do homem, à livre abertura da sociedade autênticamente democrática e humanizada?

A resposta a semelhantes indagações tem sido dada lá fora pela própria intelligentsia de maneiras diferentes e com propósitos diversos, não deixando porém de incorrer as suas várias correntes de pensamento nos exageros das formulações e tendências decodificadoras as mais contraditórias.

E temos no pólo do pessimismo demolidor, os filósofos da cultura formados nos moldes das velhas escolas européias, com iniludível inconformismo, preferindo lamentar, em seus musgosos muros ideológicos das frustrações do espírito contemporâneo, a trágica fortuna hodierna da "cultura de massa"

${ }^{2} \theta^{3}$ Edgar Morin - L'Esprit du Temps, obra traduzida entre nós sob o tíEdgar Morin - L'Esprit du Temps, obra traduzida entre nós sob e Rio
tulo de Cultura de Massas no Século XX, pela Cia. Editôra Forense, Rion
GB, 1968. 
e de sua "comunicação social". Raciocinam filosòficamente como se a inteligência como faculdade do espírito houvesse sido para sempre despojada de suas vestes de rainha, assumindo os trajes e a condição de serva da imaginação (a sua antiga escrava); e, na tríplice gradação do saber humano, a ficção não mais se subordinasse à ação (a poiesis dos gregos à sua praxis e nem esta prestasse mais a menor subserviência ao próprio conhecimento (à teoria).

Oscile entretanto o pêndulo da mesma intelligentsia em seus noventa graus do entendimento e da opção, não mais no Velho porém no Nôvo Mundo, e vamos encontrar os intelectuais do pólo oposto - o do otimismo desenfreado e badalante, - a raciocinar, incondicionalmente, em prol da "cultura de massa" e da sua padronização industrial estereotipada, transmissora de mensagens de culturas médias, para talentos médios, literaturas médias para inteligências médias e até bobagens médias para espíritos medianos. Com Marschall McLuhan à frente, os modernos teóricos americanos da "comunicação de massa" celebram não só auspiciosamente, mas com tôdas as suas extravagâncias literárias "audiovisionárias" e o seu verbalismo esotérico, o advento da era da "ditadura da imagem". "O que hoje se vê em crise - escreve McLuhan - é a própria primazia do sistema verbal e da sua lógica linear-discursiva, nos processos de informação e comunicação". E adiante: "Hoje, a roda é uma extensão do pé; o vestido da pele, e o circuito elétrico, uma extensão do sistema nervoso central". (...) "A interdependência criada (entre homens, imagem e som), pelo mundo da comunicação eletrônica, recria o próprio mundo, nos moldes de uma tribo primitiva". ${ }^{4}$

É a grande batalha moderna da invasão da imagem, condenada por gregos, endeusada por troianos, e levada à intimidade dos lares pelo vídeo - informando, deformando e compelindo, - nela pretendendo a Imaginação, esta nova deusa, a tudo fazer sobrepor, como a única testemunha dos fatos, à sua filha primogênita, à Notícia; numa espécie de tirania dos acontecimentos, exercendo sôbre a própria inteligência reitora da ação, a tirania do mundovisionismo, nesta ainda tão estranha quanto nebulosa civilização audiovisual, a que se refere com tanto entusiasmo Marschall McLuhan, no número especial da revista "Janus" de junho de 1968. "A Imaginação tomou o Poder", escreviam, por sua vez, na sua seqüência, os estudan-

4 A Galáxia de Gutenberg e O Meio é a Mensagem. Ver também "Cadernos de Jornalismo e Comunicação", n’ 10, maio de 1969, p. 22 e segs. 
tes parisienses, na fachada da Sorbonne, em seus distúrbios de rua dos idos de maio de 1968.

Para os intelectuais dos moldes clássicos, para a intelligentsia do Velho Mundo, a chamada "cultura de massa" é um simples e passageiro mergulho da humanidade nos submundos da inteligência, mais uma queda, um tropêço, do que pròpriamente uma descida definitiva aos infernos infraculturais. A própria "sociologia do fenômeno democrático", ensina Augustin Cochin, "explica inteiramente êsse fenômeno da informação", hoje entregue à sua própria sorte, trilhando os seus descaminhos livremente, nas democracias do estilo liberal-burguês e, sob a égide do seu acomodado laissez faire filosófico, limitando-se a assistir e compactuar, pela omissão, com a revolta da imaginação. ${ }^{5}$ Marcel de Corte denominou a êsse fenômeno da invasão da imagem (na terminologia de McLuhan e da sociologia americana), como já vimos, de "informação deformante", detectando nêle um produto espúrio do próprio mito moderno da democracia liberal, filha da revolução francesa e "que não existe mais", segundo êle, "senão na mente dos poucos e privilegiados profissionais dessa espécie de política"; de tal maneira se viu aquêle estilo liberal da democracia do laissez faire, laissez passer, tragado na voragem atual avassaladora da tecnologia, com as suas novas e inadiáveis exigências da planificação estatal e privatista, para a revolução econômica da produtividade. ${ }^{6} \mathrm{E}$ hoje, "só as minorias políticas, detentoras das rédeas do Estado, pretendem ainda fazer crer que tal democracia exista". ${ }^{7}$

Não nos cabe entrar aqui na análise dos méritos ou deméritos de tais debates da intelligentsia do Velho versus Nôvo Mundo. A êles só aludimos, à vôo de pássaro, para melhor situar e compreender a razão de ser e a importância da posição da intelligentsia brasileira e daquela que assumiu a nossa atual democracia face à civilização audiovisual. Eqüidistantes dos dois pólos - o do pessimismo-demolidor e o do endeusamento-otimista - sabem elas, como ensina também Edgar Morin, que nunca houve pròpriamente uma "idade de ouro da cultura" antes da revolução tecnológica e da "cultura industrial". Sabem, sobretudo, por conhecimento em causa própria, dêle náo se recusando jamais a participar, que no mundo do audiovisualismo nem sempre a inteligência se vê de todo vencida, em sua luta em prol da liberdade de criação e da autenticidade da

5 Cit. por Marcel de Corte, in L'Intelligence, en péril de mort, p. 196.

6 Liv. cit. pp. 197 e segs.

7 Idem, Idem. 
imagem e da palavra decodificadas. Além disso, a indústria cultural não produz apenas robôs e monstros, como o testemunham o cinema e não raro o próprio teatro de massa da TV, em nossos dias.

Como sistema político que pretende ao mesmo tempo criar em nosso País uma sociedade livre e aberta, partilhando, para isso, de tôdas as conquistas da revolução tecnológica e científica de nosso tempo, por sua vez, a nossa democracia, fiel à índole e à orientação da mesma intelligentsia brasileira, não poderia deixar de ter a sua própria filosofia da informação, também ela aberta e democrática. Nem poderia prescindir da missão de engajar a intelligentsia em sua civilização de vivência e em sua cultura de existencialização. Por isso, a sistemática brasileira da comunicação social, em suas grandes linhas diretivas, longe da democracia liberal, abstêmia, quando nada, orienta, sugere e educa, preferindo até se utilizar dos meios mais adequados e persuasórios da propaganda subliminar, mas, dando sempre mão forte à intelligentsia nacional, na sua luta de sobrevivência democrática para canalizar as águas transbordantes da indústria cultural, em sua voragem massificadora.

Assim, em vez de demolir, iconoclàsticamente, a cultura de massa da civilização audiovisual, ou de, ao contrário, adorá-la, como a nôvo bezerro de ouro, em seus altares da eletrônica e da automação, a intelligentsia sente-se entre nós suficientemente livre e aparelhada para conhecê-la melhor, participando dela sem o menor constrangimento ético ou intelectual, a fim de também melhor reconduzi-la aos caminhos da verdade e da autenticidade, da beleza e do bom gôsto.

Tem a nossa atual democracia, por seu lado, a sua sistemática de comunicação social, que não há de se limitar, com ser aberta e livre, aos órgãos do Serviço Público encarregados de sua coordenação e difusão, quer através do abastecimento à informação-notícia de atos e empreendimentos administrativos, quer ao fornecimento de spots educativos sempre inteligentes e oportunos à vasta rêde radiofônica nacional, quer usando mesmo da informação visual, através de filmes documentários colocados nos cinemas e de filmetes na televisão.

Embora houvesse "falado mais alto" em nossa democracia a "solução aberta", preferindo, mais democràticamente, entregar à livre emprêsa o rádio e a TV, nem por isso há de assistir ela, omissa e indiferente, ao endeusamento da desfaçatez e à glorificação do mau gôsto, trazendo a reboque a licenciosidade, o escárnio da moral e o deboche da inteligência, como 
processos de fácil enriquecimento individual, mas ao preço da deseducação coletiva e nacional. ${ }^{8}$

Todos êsses aspectos filosóficos, éticos e sociológicos da comunicação social, ou, mais notadamente, da informação visual, não nos cabe aqui aprofundar, senão referir, à guisa de considerações introdutórias e também com a intenção de meIhor acentuar a importância do problema a um tempo artístico e ético que passaremos a levantar.

Viemos, sim, comentar um simples aspecto visual da comunicação, não menos importante porém no contexto de nossa sistemática filosófica da informação, pois, se descurado, também viria fatalmente contribuir para aquela "informação deformante", a que aludimos até aqui.

É o aspecto, aparentemente mais modesto, não porém de todo secundário, do bom gôsto gráfico na apresentação do impresso oficial - livro, revista, opúsculo, boletim, etc - felizmente, bem melhor cuidado de algum tempo para cá, pelos inúmeros serviços de comunicação social administrativa. Mas que, a bem da verdade, devemos lembrar que nem sempre assim aconteceu em passado mais remoto e na própria história da evolução estética do livro oficial brasileiro.

Manuseando o catálogo comemorativo do sesquicentenário da Impressão Régia, criada a 13 de maio de 1808, e publicado em 1958 pelo Departamento de Imprensa Nacional, já podemos ter uma idéia, por mais superficial que pareça, da evolução gráfica e estética do impresso oficial em nosso País. Contudo, sòmente pesquisas mais minuciosas e atentas, feitas, entre outras fontes bibliotecárias, na Seção de Obras Raras da Biblioteca Nacional do Rio de Janeiro, de tão rico acervo, poderiam permitir-nos aquilatar melhor sôbre as grandes linhas estéticas que presidiram, através dos tempos, a evolução tipográfica oficial brasileira.

Em nossos dias, a comunicação visual não mais hesita em definir o impresso em geral e não só o livro de arte, como queria Du Ballay, como "a décima segunda Musa", ou seja: êle próprio, obra de arte e de ciência. Há uma moderna "arquitetura do impresso", com seus princípios científicos e suas leis do bom gôsto (bastaria lembrar aqui a "lei de Morrison" sôbre o correto e estético aproveitamento das margens em branco). "A tipografia - escreve Carlo Grassinelli, em seu livro Arqui-

8. Cf. O Jôgo da Verdade, 1ọ volume de discursos do Presidente Médici, edição da Secretaria de Imprensa, 1970, p. 84 e A Verdadeira Paz, 3 ? volume de pronunciamentos presidenciais, p. 132. 
tetura do Livro - como qualquer outra arte, está sujeita a convencionalismos e regras, e seu progresso não se deve à improvisação. Tenacidade, muita paciência, experimentando e tornando a experimentar, unidos a uma boa cultura técnica e artística, são elementos indispensáveis a seu êxito".

Felizmente, desde as suas origens remotas, desde a instalação da Impressão Régia, com material adquirido em Londres e aqui desencaixotado novinho em fôlha, vem o nosso impresso se beneficiando não sòmente dos inventos mecânicos, através dos tempos, mas das harmoniosas regras da arquitetura do livro, ainda que a princípio sem plena tomada de consciência de seu aspecto de comunicação visual e estética.

Não se há de menosprezar a intervenção, não só renovadora, mas conscientizadora do problema, trazida ao livro brasileiro por Pierre-François Plancher, o livreiro-editor francês fundador do Jornal do Commercio do Rio de Janeiro e que trouxe para o Brasil, em 1824, oficina tipográfica a mais completa e atualizada e oficiais em artes gráficas do melhor quilate artístico e qualificação profissional em seu tempo. Três anos após, reforçaria a sua já bem instalada e vitoriosa oficina na rua do Ouvidor com novos caixotes de máquinas impressoras e nôvo e importante refôrço também de "famílias" de tipos gráficos móveis, as mais belas de seu tempo, além do material e de três oficiais de litografia, que fariam aqui os primeiros impressos em côres de nossa história tipográfica.

A crônica das rivalidades sôbre bom gôsto gráfico, tão proveitosas para o incipiente livro nacional, travadas, de um lado, entre Pierre-François Plancher, sua mulher Emilie e seu filho, Seignot Plancher, e, do outro, os oficiais e diretores da Impressão Régia, está tôda ela contada nas colunas tanto do Diário do Rio de Janeiro, como do primitivo jornal do livreiro-editor gaulês, 0 Spectador Brasileiro, bem como em seus diferentes Almanaks, entre 1827 e 1832, quando já aparece como "impressor livreiro de S.M. o Imperador" e dos próprios Anais da Assembléia dos Deputados. O bom gôsto do impresso francês da época, assim, viria aqui rivalizar com o da influência inglêsa, via Lisboa, da Impressão Régia. O prestígio do livreiro-editor francês não só levaria a sua fama até fins do século XIX - quando vemos Machado de Assis, em Quincas Borba, marcar encontro entre dois personagens, "na livraria do Plancher, à rua do Ouvidor" - mas influenciaria, tipográfica e estèticamente, a livreiros-editôres cariocas como os irmãos Garnier e o próprio Paula Brito, saído das oficinas do Jornal do Commercio. 
Não parou aí o livro nacional, mas, a partir de 1860 , recebia e aculturava, numa fusão com a influência gaulesa e a britânica, outras influências, alemãs, italianas, espanholas e néolusitanas. Tratam-se de inovações apenas do grafismo capista, evoluindo dos estilos barroco e rococó iniciais, anglo-lusitanos, após assimilar o estilo francês diretoriano, para o grafismo neorococó, apenas de fachada, ou quanto à capa; pois, quanto à diagramação interna, ou do "miolo", ou texto mesmo do impresso, permanece a influência francesa e diretoriana, desconhecedora, ou menosprezando, propositadamente, as "leis de Morrison", às quais até hoje são fiéis os livros anglo-saxônicos.

Vivia então o nosso periodismo do século XIX seus tempos áureos da caricatura, parasitando o livro nacional as suas influências benéficas, como entre outras, as de Henrique Fleiuss, Angelo Agostini, Joseph Mil, Augusto Offi, Luigi Borgomainerio, sem esquecer o maior caricaturista lisboeta de seu tempo, Rafael Bordalo Pinheiro, que aqui andou imigrado. É a grande fase do emolduramento capista do livro brasileiro e que conheceu dois estilos diferentes de apresentação: a do chamado livro-vinheta e a do livro-cartaz. Exemplo típico do primeiro é o volume existente na Biblioteca Nacional do Rio de Janeiro intitulado Histórico da Companhia Industrial de Mangaratiba, de Sebastião Soares, utilizando em corpos 8 e 12, belos caracteres da famosa "família" tipográfica holandesa "EIzevir" e trazendo na capa, como vinheta, o desenho de uma locomotiva com seu carro-trolley de carvão.

Por volta de 1871 , seria o livro-vinheta substituído nas estantes oficiais pelo livro-cartaz, o livro-affiche da época neo-rococó. Exemplo bem típico é a cópia-autografada do famoso Fac-simile da Constituição dos Estados Unidos do Brasil, de 24 de fevereiro de 1891, existente na Câmara Federal.

Em nosso Mil e Novecentos gráfico, enquanto o periodismo se renova, atualizando-se segundo os novos moldes tipográficos europeus, impresso inclusive em côres, o livro oficial, como o livro brasileiro em geral, vai conhecer mais de três décadas de completo anarquismo gráfico arquitetônico, caindo verticalmente de padrão estético e menosprezando as mais comezinhas leis científicas de aproveitamento do espaço em prêto e das margens e da escolha dos tipos adequados. Sem falar do mau gôsto gráfico que a pouco e pouco o insula, ante a categoria do impresso internacional.

Datam apenas da década de 40 a renovação e modernização do livro particular e, da de 50 , as do impresso oficial. Pela primeira vez, em nossa evolução gráfica, o livro toma consciên- 
cia de sua harmoniosa arquitetura, tão exigente quanto a da casa e a do templo e de que a sua feitura é ao mesmo tempo uma ciência e uma arte. O artista gráfico paraibano Tomás Santa Rosa, após modernizar o livro particular, com as edições de Schmidt e da Livraria Editôra José Olympio, é chamado, quase simultâneamente, pelo Itamarati e a Casa de Rui Barbo$\mathrm{sa}$, a fim de modernizar suas edições. Moderniza-as porém na base do letrismo capista e de uma sóbria e gaulesa implantação (ou quase reimplantação) das leis de Morrison, na diagramação interna de tais impressos oficiais.

Bem mais ousado se torna Santa Rosa, quando, estimulado por Simeão Leal, moderniza os impressos do Serviço de Documentação do MEC. Voltam entre nós os tipos das "famílias" famosas, - os Elzevir, Garamond, Bodoni, Didot, o Electra, de Eric Gill - a enriquecer a diagramação brasileira do impresso, livro, catálogo de exposições, revistas, separatas, boletins oficiais, etc. A revista Cultura daquela fase é bem típica, além do nôvo e alto padrão gráfico com que passa a ser tratado o próprio livro de arte no Brasil.

$\mathrm{Na}$ década de 60 , tornaria a conhecer nosso impresso oficial uma fase inexpressiva, de mau gôsto gráfico e de anarquismo arquitetônico, para, na década de 70, retomar aquela sua linha de modernização e beleza arquitetônica inaugurada em 50. Basta citar aqui, como obras representativas dêsse esfôrço modernizador e estético do livro, a trilogia dos discursos do Presidente Médici, composta e impressa pelo DIN para a Secretaria de Imprensa, obras, de fato, gràficamente dignas das linhas arquitetônicas de beleza ímpar como são os Palácios da Alvorada e do Planalto e não seria mesmo compreensível que nesta fase de evolução artística da informação visual não se apresentassem com o bom gôsto que presidiu o layout das capas e a diagramação interna.

Não poderíamos esquecer publicações como as do Ministério dos Transportes, do Planejamento, da Fazenda, do MEC e a própria renovação gráfica atual da revista do DASP, entre tantas que se modernizam e atualizam de acôrdo com as mais recentes exigências da comunicação visual. Pois, também do ponto de vista da boa apresentação artística, a informação visual contribui para educar o povo, também ela combate aquela "informação deformante", a que aludíamos no início dêsse artigo e que a intelligentsia e a democracia brasileiras estão empenhadas em impedir seja endeusada e glorificada, nos atuais altares eletrônicos da "cultura de massa", por sua industrialização massificadora. 
